\title{
Naviculales (Bacillariophyta) from coastal waters of the Gulf of San Matías (Province of Río Negro, Argentina)
}

\section{Naviculales (Bacillariophyta) de aguas costeras del Golfo San Matías (Provincia de Río Negro, Argentina)}

\author{
InÉS SUNESEN* \& EUgENIA A. SAR
}

División Ficología, Facultad de Ciencias Naturales y Museo, Universidad Nacional de La Plata, Argentina. Consejo Nacional de Investigaciones Científicas y Técnicas, CONICET, Argentina.

*isunesen@fcnym.unlp.edu.ar

\begin{abstract}
RESUMEN
El presente estudio está focalizado en la morfología y distribución de especies de los géneros Berkeleya, Amicula, Cocconeiopsis, Haslea y Fallacia procedentes de aguas costeras marinas templadas del Golfo San Matías (Prov. de Río Negro, Argentina). El material fue colectado con red de plancton de $30 \mu \mathrm{m}$ de apertura de malla y analizado con microscopía óptica y electrónica de barrido. El género Amicula y dos especies A. specululum y Fallacia margino-punctata son reportados por primera vez para aguas costeras sudamericanas. El género Cocconeiopsis y C. pullus son reportados por primera vez para Argentina y Haslea quarnerensoides es reportada por primera vez para Sudamérica.
\end{abstract}

Palabras clave: Diatomeas, distribución, Naviculales, primera cita de géneros y especies, ultraestructura.

\begin{abstract}
This study is focused on morphology and distribution of species of the genera Berkeleya, Amicula, Cocconeiopsis, Haslea and Fallacia from the temperate marine coastal waters of the Gulf of San Matías (Prov. of Rio Negro, Argentina). Material was collected with $30 \mu \mathrm{m}$ net hauls and analyzed in light and scanning electron microscopy. The genus Amicula and two species A. specululum and Fallacia margino-punctata are reported for the first time from South American coastal waters. The genus Cocconeiopsis and C. pullus are reported for first time for Argentina and Haslea quarnerensoides is reported for the first time from South America.
\end{abstract}

KEYWORDS: Diatoms, distribution, first report of genera and species, Naviculales, ultrastructure.

\section{INTRODUCTION}

The Order Naviculales Bessey emend. Mann in Round et al. (1990) is characterized by solitary or chain-forming cells with one, two or four lamina-shaped chloroplasts, rarely $\mathrm{H}$-shaped or discoid. The central nucleus is rarely eccentric. The frustules are isovalvar with simple or loculated areolae occluded by hymenes. The raphe is central or slightly eccentric, straight or sigmoid, and rarely bi-arched. Internally, the central raphe endings are straight, hooked or T-shaped and the terminal endings finish in helictoglossae. Externally, the terminal raphe fissures are curved towards the same side or more commonly towards opposite sides. The cingulum is formed by open bands. According to Round et al. (1990), the Naviculales from marine, freshwater and brackish water habitats are predominantly epipelic. They can also be found in epiphytic, benthic and subaerial environments, and more rarely in planktonic habitats (Stauropsis Ehrenberg, some species of Haslea Simonsen, Proschkinia Karayeva, and a stage of Phaeodactylum von Bohlin).

Within the framework of studying phytoplanktonic diatom populations from the Gulf of San Matías (Province of Río Negro, Argentina), some species assigned to the Naviculales were found in net samples. Studies of taxa from the order Naviculales from marine coastal environments along the Argentinian coast, using light and scanning electron microscopy are scarce and devoted to taxa within the genera Pleurosigma W. Smith (Ferrario \& Sar 1990, Sar et al. 2012, 2013, 2014, Sunesen et al. 2013), Trachyneis Cleve (Sar 1996) and Haslea (Cefarelli et al. 2018). Small, 
infrequent and / or very rare species found in phytoplankton from Argentinian coastal waters have not been treated and remain little known.

The aim of the present study is to analyze species from the genera Berkeleya Greville, Amicula Witkowski, LangeBertalot \& Metzeltin, Cocconeiopsis Witkowski, LangeBertalot \& Metzeltin, Haslea and Fallacia Stickle \& Mann found in the study area, and to provide details on their morphology, taxonomy and distribution.

\section{MATERIAL AND METHODS}

The analyzed material was collected at several stations in the northern part of the Gulf of San Matías (Province of Río Negro): Punta Orengo, Las Garzas, Banco Reparo, San Antonio Oeste, Los Alamos, Las Grutas, Piedras Coloradas, El Sótano and El Fuerte (Fig. 1). Sampling was carried out from April 1998 to May 2000 and from March 2006 to April 2007 (Table 1). The area is characterized by a strong resuspension of bottom material caused by tidal currents in the shallow waters of the Bay of San Antonio and neighbouring coastal environments, which explains the frequent occurrence of benthic taxa in the phytoplankton.

In the northern area of the Gulf of San Matías, seawater temperature ranges from $7.0-23.5{ }^{\circ} \mathrm{C}$ with salinity ranging from 34-36 psu (Pascual et al. 2001). Qualitative samples were taken from the surface layer of the water column (between 0 and $5 \mathrm{~m}$ ) with $30 \mu \mathrm{m}$ net hauls and fixed in situ with $4 \%$ formalin. In the laboratory, the preserved samples were rinsed with distilled water to remove salt and preservatives, and then the organic matter was oxidized according to Hasle \& Fryxell (1970) and Prygiel \& Coste (2000). The cleaned material was mounted for light (LM) and scanning electron microscopy (SEM) according to Ferrario et al. (1995). Permanent mounts were made with Hyrax or Naphrax (Brunel Microscopes, Chippenham, UK).

Material was deposited in the Colección de Diatomeas Argentinas, División Ficología "Dr. Sebastián A. Guarrera", Facultad de Ciencias Naturales y Museo, Universidad Nacional de La Plata under the accession numbers LPC 4550-4644, and LPC 13648-13685. Slides, processed materials and samples from the field share the same LPC number.

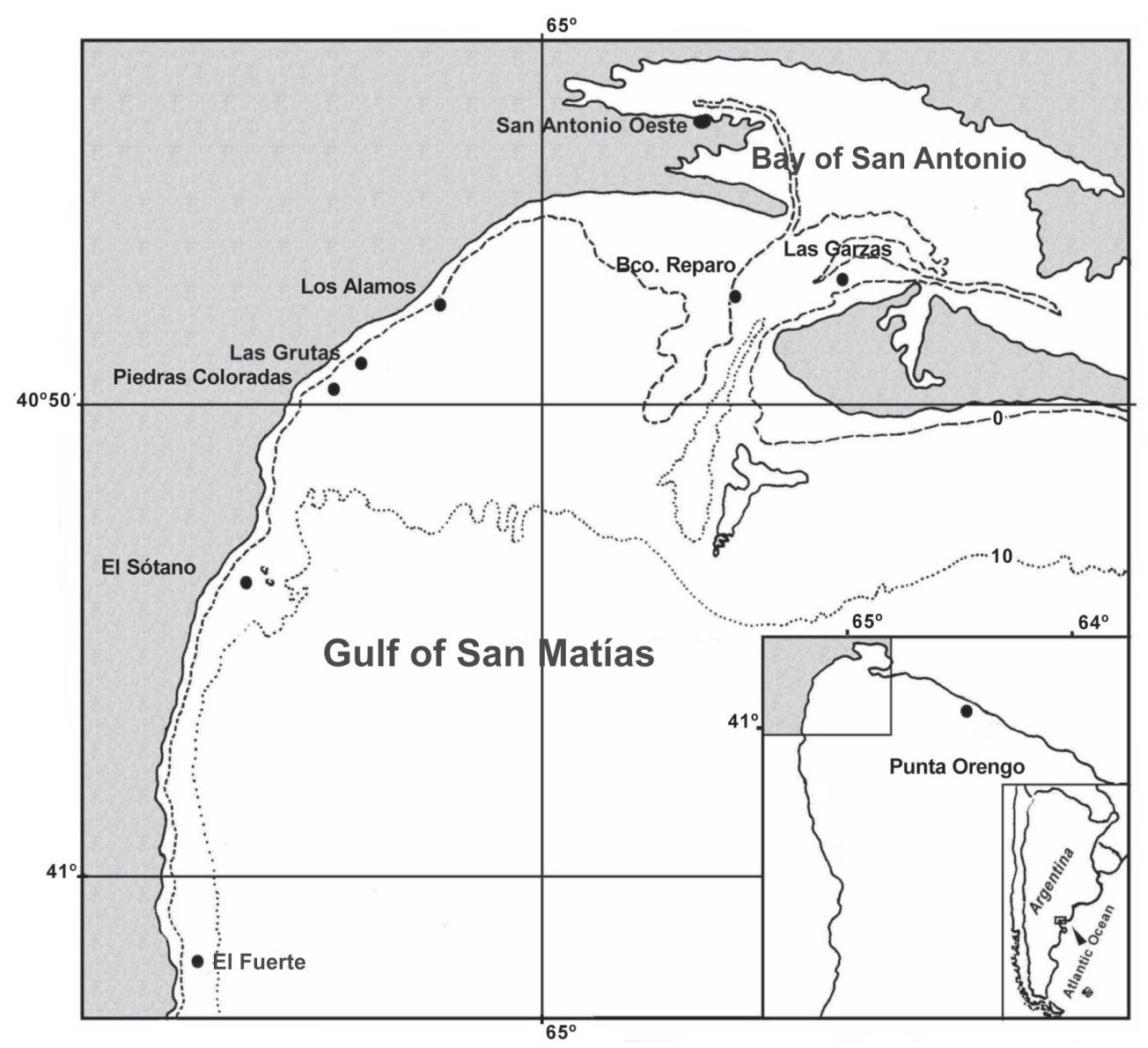

FIgURE 1. Map of the Northern region of the Gulf of San Matías showing sampling stations and location of the study area in Argentina. / Mapa de la región Norte del Golfo San Matías mostrando estaciones de muestreo y localización del área de estudio en Argentina. 
TABLE 1. Key to sampling stations, dates of collection and sample numbers at the Herbarium (LPC). / Clave de estaciones de muestreo, fechas de colecta y número de muestras en el Herbario (LPC). PO: Punta Orengo, LGz: Las Garzas, BR: Banco Reparo, SAO: San Antonio Oeste, LA: Los Alamos, LG: Las Grutas, PC: Piedras Coloradas, ES/BO: El Sótano / Bajo de Oliveira, EF: El Fuerte.

\begin{tabular}{|c|c|c|c|c|c|c|c|c|c|}
\hline DATE & $\mathrm{PO}$ & $\mathrm{LGz}$ & $\mathrm{BR}$ & $\mathrm{SAO}$ & LA & LG & $\mathrm{PC}$ & $\mathrm{ES} / \mathrm{BO}$ & $\mathrm{EF}$ \\
\hline $16-22 / 04 / 1998$ & & & 4553 & & 4552 & 4550 & & 4551 & \\
\hline $04-26 / 05 / 1998$ & & & 4571 & & 4570 & 4568 & & 4569 & 4563 \\
\hline $16-18 / 06 / 1998$ & & & 4575 & & & 4573 & & 4572 & 4574 \\
\hline $19 / 06 / 1998$ & & & & & 4577 & 4576 & & & \\
\hline $15-30 / 07 / 1998$ & & & 4580 & & 4581 & 4578 & & 4579 & \\
\hline 04-08/08/1998 & & 4585 & & & & 4583 & & 4582 & \\
\hline $02-22 / 09 / 1998$ & & & 4588 & & & & & $4586 / 4589$ & \\
\hline $06-27 / 10 / 1998$ & & & & & & 4593 & & 4592 & 4590 \\
\hline $10-26 / 11 / 1998$ & & & & & & 4594 & & & 4595 \\
\hline 03/12/1998 & & & & & & 4596 & & & \\
\hline $02 / 02 / 1999$ & & & & & & 4597 & & & \\
\hline $15-20 / 02 / 1999$ & 4600 & & 4601 & & & 4598 & & 4599 & \\
\hline $15-20 / 03 / 1999$ & 4602 & & 4605 & & & 4603 & & 4604 & \\
\hline $13-30 / 04 / 1999$ & 4606 & & 4607 & & & & & 4608 & \\
\hline $04-12 / 05 / 1999$ & 4610 & & & & 4611 & 4609 & & & \\
\hline 27/05/1999 & & & & & & 4612 & & 4618 & \\
\hline 01-08/06/1999 & 4619 & & & & & 4622 & & & \\
\hline 22/07/1999 & & & & & & & & 4620 & \\
\hline 25/08/1999 & & & & & & & & 4623 & \\
\hline $16 / 09 / 1999$ & & & & & & 4624 & & 4625 & \\
\hline 04/10/1999 & & & & & & 4626 & & & \\
\hline $24-26 / 11 / 1999$ & & & & & & 4628 & & 4627 & \\
\hline $03-09 / 02 / 2000$ & & & & & 4631 & 4630 & 4629 & 4632 & \\
\hline $24-29 / 02 / 2000$ & & & & 4635 & & 4633 & & 4634 & \\
\hline $24-26 / 05 / 2000$ & & & & & & & 4644 & & \\
\hline 04/03/2006 & & & & & & & 13648 & & \\
\hline $22 / 03 / 2006$ & & & & & & 13650 & 13649 & & \\
\hline 05/04/2006 & & & & & & 13651 & 13652 & & \\
\hline $25 / 04 / 2006$ & & & & & & 13656 & 13655 & & \\
\hline $13 / 05 / 2006$ & & & & & & 13657 & 13658 & & \\
\hline $25 / 05 / 2006$ & & & & & & 13653 & 13654 & & \\
\hline $26 / 05 / 2006$ & & & & & & 13664 & 13665 & & \\
\hline $14 / 06 / 2006$ & & & & & & 13673 & 13667 & & \\
\hline $25 / 07 / 2006$ & & & & & & 13670 & 13669 & & \\
\hline $31 / 07 / 2006$ & & & & & & 13668 & & & \\
\hline $05 / 08 / 2006$ & & & & & & 13672 & 13671 & & \\
\hline 01/09/2006 & & & & & & 13674 & 13675 & & \\
\hline $19 / 09 / 2006$ & & & & & & 13676 & 13677 & & \\
\hline $19 / 11 / 2006$ & & & & & & 13678 & 13679 & & \\
\hline $03 / 02 / 2007$ & & & & & & & 13681 & & \\
\hline $21-23 / 02 / 2007$ & & & & & & 13682 & 13683 & & \\
\hline $01 / 04 / 2007$ & & & & & & 13684 & 13685 & & \\
\hline
\end{tabular}


Observations and microphotographs were made with the light microscopes Nikon Microphot-FX (phase contrast; Nikon Instruments Inc., Tokyo), Leica DM 2500 (phase contrast and differential interference contrast; Leica Microsystems, Wetzlar, Germany) and Zeiss Axiovert 40 CFL (phase contrast and DIC; Zeiss Microimaging, Göttingen, Germany). Scanning electron microscopy was performed using Jeol JSMT 100 and Jeol JSM 6360 LV (Jeol, Tokyo, Japan) electron microscopes.

The terminology used in this study followed Ross et al. (1979) and Round et al. (1990). The classification scheme followed Round et al. (1990).

\section{RESULTS}

\section{BERKELEYACEAE}

Berkeleya Greville emend. Cox, 1975: 214

Berkeleya rutilans (Trentepohl ex Roth) Grunow emend. Cox

Fig. 2 a-e

Basionym: Conferva rutilans Trentepohl ex Roth 1806: 179. Synonym: Amphipleura rutilans (Trentepohl ex Roth) Cleve 1894: 126.

References: Cox 1975: 205, figs 1-5, 8, 12, 13, 20, 30, 3235; Lobban 1984: 781, figs. 4 c, 5 a-f.

Solitary cell, lying in valvar view. Narrow-elliptic to ellipticlanceolate valves, with obtuse apices, length 17.0-21.0 $\mu \mathrm{m}$ and width 3-4 $\mu \mathrm{m}$ (Fig. 2 a-d) $(\mathrm{n}=17)$. Valve face slightly curved down in a shallow valve mantle, with an external asymmetric apical hyaline area (Fig. 2 a, b). Uniseriate striae, 30-34 in $10 \mu \mathrm{m}$ in the centre and denser towards the apices, $40-44$ in $10 \mu \mathrm{m}$, parallel to slightly radiate at centre, convergent towards apices, and surrounding apices (Fig. 2 a-c). Areolae adjacent to central area transapically elongated (Fig. 2 a-d). Raphe branches are short, with central and terminal external fissures curved in same lateral direction (Fig. 2 a, b). Internally, a conspicuous median sternum extends along the central area and bears two short, asymmetric raphe branches finishing in helictoglossae (Fig. 2 c-e). Girdle composed of open bands (Fig. 2a).
Photographed material: LPC 4609, Las Grutas, 04/04/1999; LPC 13664, Las Grutas, 26/05/2006.

Distribution: Berkeleya rutilans is a cosmopolitan widespread marine species frequently found growing in mucilage tubes with vast numbers of cells closely packed together. It was found occasionally in phytoplankton samples from Las Grutas, Banco Reparo, El Sótano, and Piedras Coloradas as scarce in spring, summer and fall (Table 2). Previously, Ferrario \& Sar (1984) reported this taxon from marine coastal waters of Puerto Deseado, Province of Santa Cruz, and Maidana \& Romero (1995) from inland waters of a hypersaline lake in the Province of La Pampa. Witkowski et al. (2000) reported the species as abundant in marine to brackish-waters from the Arctic to the tropics and Hamsher \& Saunders (2014) recorded it from the Antarctic, Chile, Europe and Japan. Recently, Fricke et al. (2017, Fig. 3 a-e) found long, unbranched mucilage tubes of $B$. rutilans, reaching lengths of over 20 $\mathrm{cm}$, attached to different types of hard substrates, forming blooms in San Antonio Oeste channel.

\section{Naviculaceae}

Amicula Witkowski, Lange-Bertalot \& Metzeltin, 2000: 127, 420.

Amicula specululum (Witkowski) Witkowski in Witkowski, Lange-Bertalot \& Metzeltin 2000

Fig. 3 a-d

Basionym: Navicula specululum Witkowski 1994: 159, pl. 36: figs. 5-12.

References: Witkowski, Lange-Bertalot \& Metzeltin 2000: 127, 420, pl. 65, figs 1-14.

Solitary cell, usually lying in valvar view. Elliptic valve, with broadly rounded apices. Length 5.0-6.0 $\mu \mathrm{m}$, and width 3.0-3.5 $\mu \mathrm{m}$ (Fig. $3 \mathrm{a}-\mathrm{d}$ ). Valve face almost flat, mostly hyaline, with elliptic areolae restricted to barely differentiated valve margins. Striae 34-38 in $10 \mu \mathrm{m}$ (Fig. 3 a, b) $(n=18)$. Straight raphe without external fissures, proximal endings coaxial and simple or slightly expanded, and terminal endings distant from the valve apices (Fig. 3 a, b). Raphe-sternum thickened internally (Fig. 3 c, d). Central raphe endings coaxial and terminal raphe endings finished in small, inconspicuous helictoglossae (Fig. 3 c, d).

TABLE 2. Temporal distribution of the species along the year. / Distribución temporal de las especies a lo largo del año.

\begin{tabular}{|c|c|c|c|c|c|c|c|c|c|c|c|c|}
\hline SPECIES & $\mathrm{J}_{\mathrm{AN}}$ & FEB & MAR & APR & MAY & Jun & JuL & Aug & SEP & OCT & Nov & DEC \\
\hline Berkeleya rutilans & & $\mathrm{X}$ & $\mathrm{X}$ & $\mathrm{X}$ & $\mathrm{X}$ & & & & $\mathrm{X}$ & & $\mathrm{X}$ & \\
\hline Amicula specululum & & $\mathrm{X}$ & $\mathrm{X}$ & & $\mathrm{X}$ & & & & $\mathrm{X}$ & $\mathrm{X}$ & & $\mathrm{X}$ \\
\hline Cocconeiopsis pullus & & $\mathrm{X}$ & & $\mathrm{X}$ & $\mathrm{X}$ & & $\mathrm{X}$ & $\mathrm{X}$ & $\mathrm{X}$ & & & $\mathrm{X}$ \\
\hline Haslea quarnerensoides & & $\mathrm{X}$ & & $\mathrm{X}$ & $\mathrm{X}$ & $\mathrm{X}$ & $\mathrm{X}$ & $\mathrm{X}$ & $\mathrm{X}$ & & $\mathrm{X}$ & \\
\hline Fallacia margino-punctata & & & & & $X$ & $X$ & & & & & & $X$ \\
\hline Fallacia vittata & & & & $\mathrm{X}$ & $\mathrm{X}$ & $\mathrm{X}$ & $\mathrm{X}$ & & $\mathrm{X}$ & $\mathrm{X}$ & $\mathrm{X}$ & $\mathrm{X}$ \\
\hline
\end{tabular}



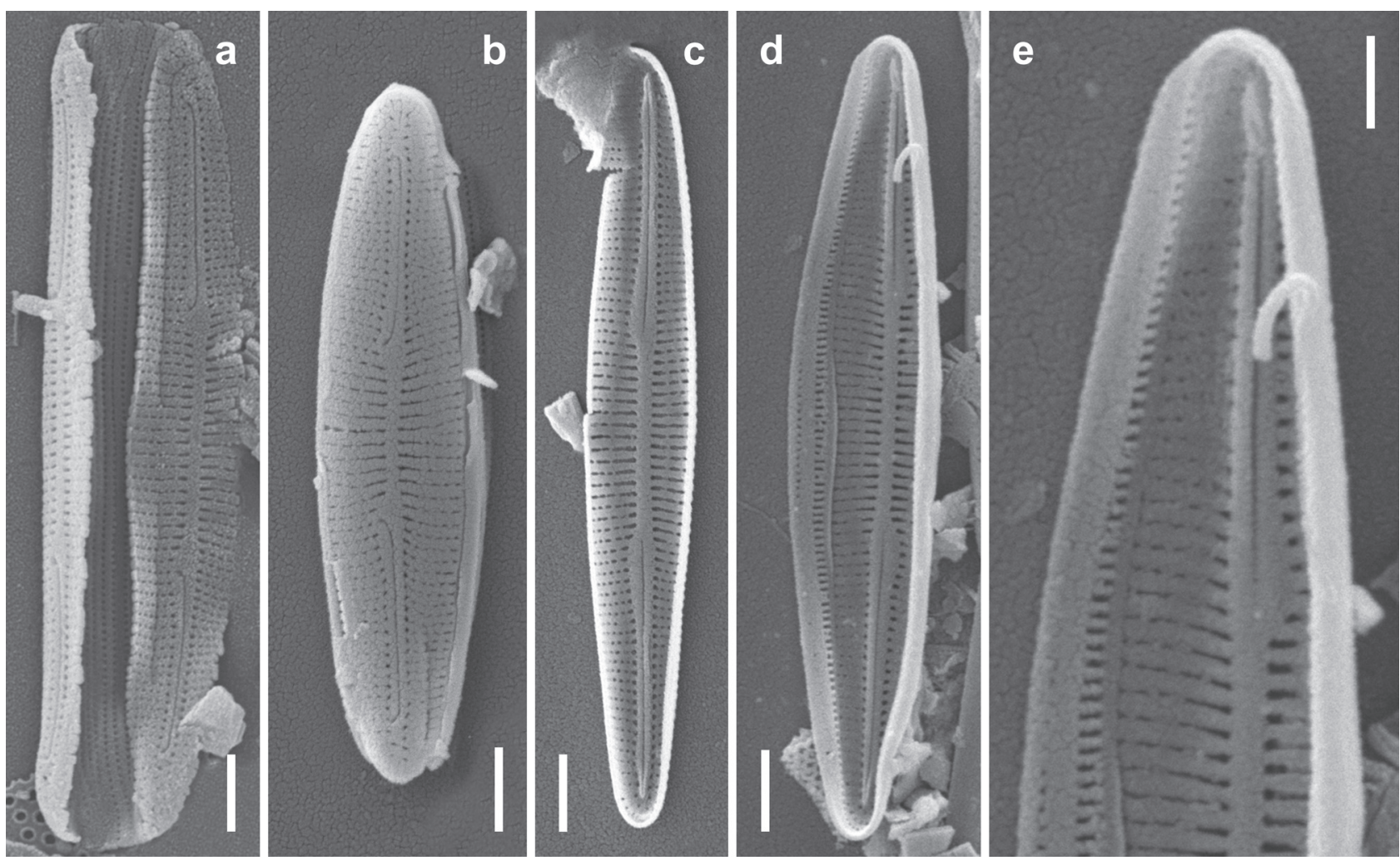

Figure 2. Berkeleya rutilans. a-e. Scanning electron microscopy. a, b. External view. a. Tilted frustule in girdle view. b. Frustule in valve view. c-e. Internal view. c. Valve showing a conspicuous median sternum and short raphe branches terminating in helictoglossae. d. Valve with an open valvocopula showing two rows of poroids. e. Detail of the Fig. 2 d. Note helictoglossa. Scale bars $=2 \mu \mathrm{m}(\mathrm{a}-\mathrm{d}) ;=1 \mu \mathrm{m}$ (e). / a-e. Microscopía electrónica de barrido. a, b. Vista externa. a. Frústulo inclinado en vista conectival. b. Frústulo en vista valvar. c-e. Vista interna. c. Valva mostrando un conspicuo esternón medio y ramas del rafe cortas terminando en helictoglossae. d. Valva con una valvocopula abierta mostrando dos hileras de poroides. e. Detalle de la Fig. 2 d. Note helictoglossa. Escalas $=2 \mu \mathrm{m}(\mathrm{a}-\mathrm{d}) ;=1 \mu \mathrm{m}(\mathrm{e})$.
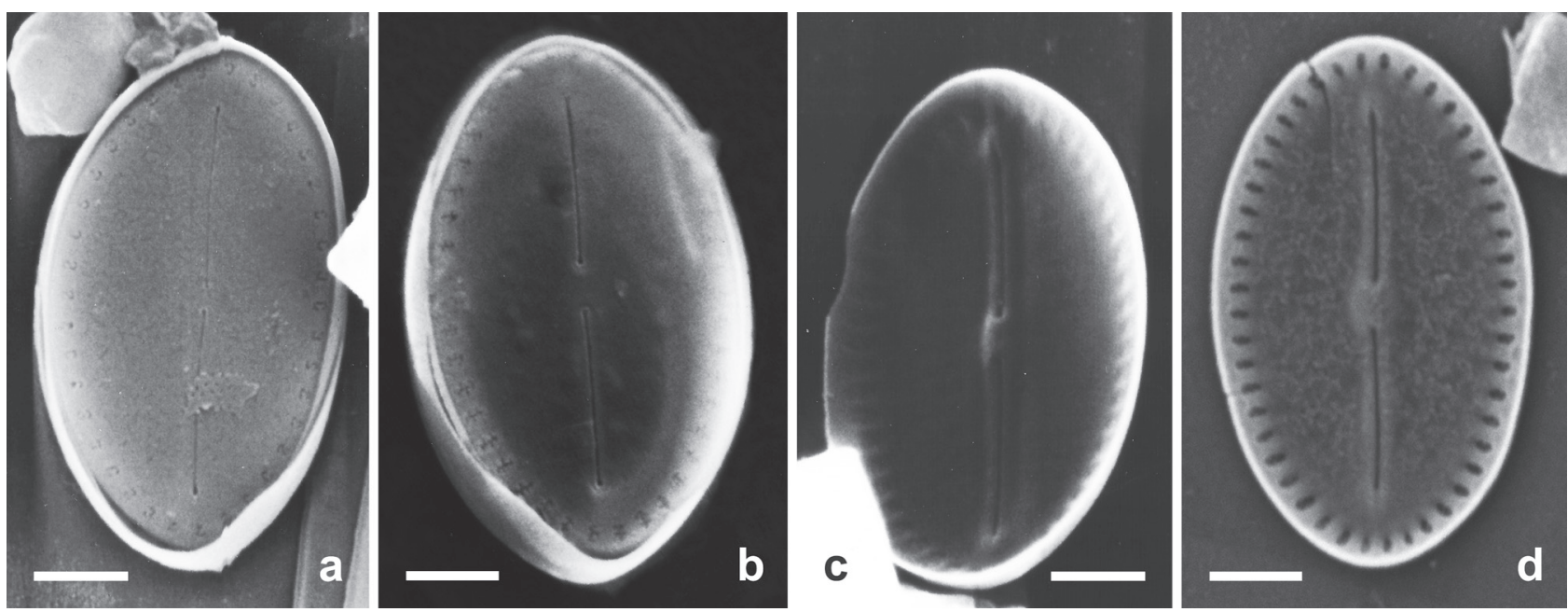

Figure 3. Amicula specululum. a-d. Scanning electron microscopy. a, b. External view. Valves with elliptic areolae near the margin. Note terminal raphe endings distant from the apices. c, d. Internal view. c. Tilted valve showing thickened raphe-sternum and a ring of marginal areolae internally occluded by hymenes. Scale bars $=1 \mu \mathrm{m}$. / a-d. Microscopía electrónica de barrido. a, b. Vista externa. Valvas con areolas elípticas cerca del margen. Note los extremos distales del rafe distantes de los ápices. c, d. Vista interna. c. Valva inclinada mostrando rafeesternón engrosado y un anillo de areolas marginales internamente ocluidas por hymenes. Escalas $=1 \mu \mathrm{m}$. 
Gayana Bot. 76(1), 2019

Photographed MATERIAL: LPC 4596, Las Grutas, 03/12/1998; LPC 4598, Las Grutas, 15/02/1999; LPC 4610, Punta Orengo, 07/05/1999; LPC 13648, Piedras Coloradas, 04/03/2006; LPC 13675, Piedras Coloradas, 01/09/2006.

Distribution: Amicula specululum was described from Puck Bay, Poland, as rare to sparse in sediments (Witkowski 1994). It was subsequently reported by Witkowski et al. (2000) from the Indian Ocean coast in Kenya and from Florida, United States of America. Recently the species was reported as benthic from the Caspian Sea (Karayeva \& Bukhtiyarova 2010: 472, pl. 1, fig. 1) and from Cape Fiolent Reserve, Crimea, Black Sea (Nevrova 2016: figs 1, 7). A. specululum was found only occasionally in all seasons of the year in phytoplankton samples from Punta Orengo, Las Grutas and Piedras Coloradas (Table 2). It was also found living on Codium Stackhouse from a grab sample (unpublished data). This is the first record of the genus and species from South American coastal waters.

Cocconeiopsis A. Witkowski, H. Lange-Bertalot \& D. Metzeltin 2000: 172.

Cocconeiopsis pullus (Hustedt) A. Witkowski, H. LangeBertalot \& D. Metzeltin, 2000.

Fig. 4 a-h

Basionym: Navicula pullus Hustedt 1955: 30, pl. 7, fig. 18. References: Witkowski, Lange-Bertalot \& Metzeltin 2000: 175, pl. 67, figs. 29, 30; Simonsen 1987: 415, pl. 616, figs. 16-18.

Solitary cell, commonly lying in valvar view. Elliptic valves with broadly rounded apices, length 7.7-11.0 $\mu \mathrm{m}$, and width 4.3-6.0 $\mu \mathrm{m}$ (Fig. $4 \mathrm{a}-\mathrm{h})(\mathrm{n}=22)$. Valve surface almost flat curving gently in a shallow mantle (Fig. 4 b-e). Uniseriate striae radiate throughout, slightly curved towards the poles, 25-30 in $10 \mu \mathrm{m}$ in central part of valve and slightly denser towards apices, 30-35 in $10 \mu \mathrm{m}$ (Fig. $4 \mathrm{~b}$-g). Unilateral central trapezoidal area on valve surface without striae or with ghost striae (Fig. 4 e, f). Areolae subcircular to elongated, smaller in outer than in inner view, and internally occluded (Fig. $4 \mathrm{~h}$ ). Areolae at the valve mantle more elongated (Fig. 4 d, f arrowheads). Raphe almost straight without external fissures, with coaxial proximal endings depressed in siliceous layer, terminal endings finished at certain distance from apices (Fig. 4 b-f). Raphe-sternum narrow bordered by transapical striae or a line of isolated areolae in the unilateral central trapezoidal area (Fig. 4 d-f). Internally, central raphe endings simple and coaxial and central and terminal raphe endings terminate in a small, inconspicuous helictoglossae (Fig. 4 g, h).

Photographed material: LPC 4583, Las Grutas, 08/08/1998; LPC 4596, Las Grutas, 03/12/1998; LPC 4598, Las Grutas, 15/02/1999; LPC 4600, Punta Orengo, 16/02/1999; LPC
4610, Punta Orengo, 07/05/1999; LPC 13665, Piedras Coloradas, 26/05/2006; LPC 13669, Piedras Coloradas, 25/07/2006.

Distribution: This species was described from Beaufort Bay, North Carolina as Navicula pullus (Hustedt 1955), subsequently transferred to the genus Cocconeiopsis as C. pullus (Witkowski et al. 2000) and reported from the Mississipi Delta, United States of America. Recently, the species was found from the Santa Catarina coastal waters, Brazil (Garcia \& Bärwaldt Dutra 2013: 220, figs 27-34) and from Cape Fiolent Reserve, Crimea, Black Sea (Nevrova 2016: figs 1, 11). The species was found only occasionally in all seasons of the year, as scarce, in phytoplankton samples from Punta Orengo, Las Garzas, Banco Reparo, Las Grutas and Piedras Coloradas (Table 2). This is the first record of the genus and the species for Argentina.

Haslea R. Simonsen, 1974: 46

References: Massé et al. 2001: 625.

Haslea quarnerensoides (Hustedt) Navarro, Micheli \& Navarro 2000: 113.

Fig. 5 a-p

Basionym: Navicula quarnerensoides Hustedt 1961: 49, fig. 1203.

References: Simonsen 1987: 471, pl. 725, figs. 6-9.

Solitary cells, commonly lying in valvar view. Valve fusiform, with acute apices, 79-110 $\mu \mathrm{m}$ long, and 10-13 $\mu \mathrm{m}$ wide $(\mathrm{n}=22)$. In LM, valve surface almost hyaline, with subtle transapical striae, crossed by delicate apical striae (Fig. 5 a-c). Raphe straight and central, crossed by a perpendicular pseudostauros in central valve (Fig. 5 a-c). In SEM, valve surface curves down in a shallow mantle deeper towards apices and externally crossed by longitudinal strips of silica separated by narrow slits (Fig. 5 d, e, h-l) that merge with a continuous peripheral slit around apices (Fig. 5 j-1). Internally, transapical striae uniseriate and parallel throughout the valve, $25-27$ in $10 \mu \mathrm{m}$, with central virgae thickened forming a pseudostauros (Fig. $5 \mathrm{f}$, $\mathrm{g}, \mathrm{m}, \mathrm{n})$. Areolae subcuadrangular, longitudinally aligned forming apical striae, 20-21 in $10 \mu \mathrm{m}$ (Fig. $5 \mathrm{~m}$-p). External axial area narrow and inconspicuous (Fig. 5 h-k). Raphe branches straight with central raphe fissures unilaterally deflected (Fig. 5 h) or almost straight (Fig. 5 i) and terminal fissures strongly deflected to the same side, almost abutting peripheral slit (Fig. 5 j-1). Raphe sternum flanked by an accessory axial rib, on the primary side of valve and by a shorter and thinner central rib, on the secondary side (Fig. $5 \mathrm{~m}, \mathrm{n})$. Axial rib covers raphe-sternum throughout most of the valve, except at centre and apices (Fig. 5 m-p). Central raphe endings are coaxial (Fig. $5 \mathrm{~m}, \mathrm{n}$ ) and terminal raphe endings terminate in a long helictoglossa (Fig. 5 o, p). Central virgae continuous with axial and central ribs (Fig. $5 \mathrm{~m}, \mathrm{n})$. 

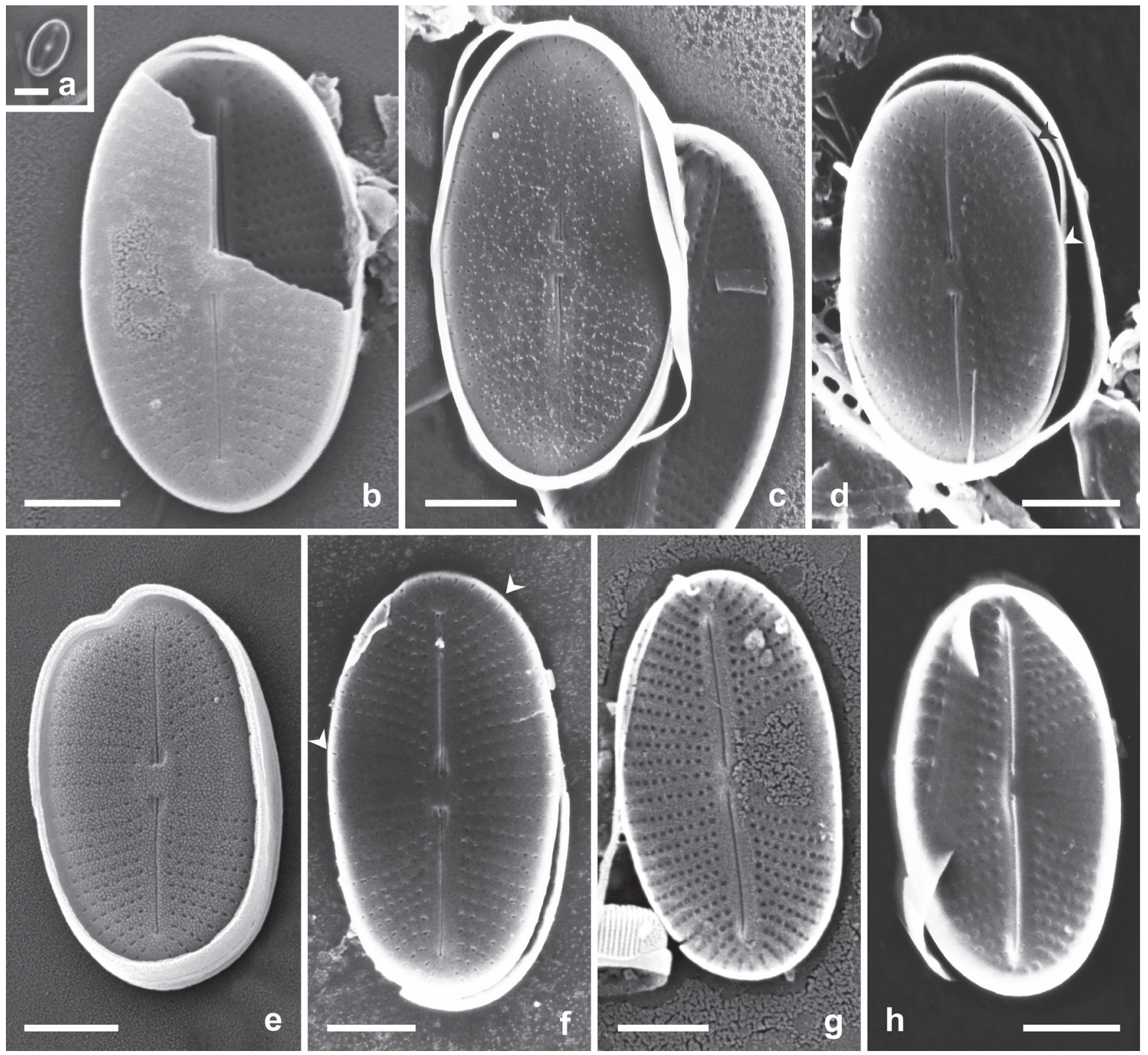

Figure 4. Cocconeiopsis pullus. a. Light microscopy. General view of the valve. b-h. Scanning electron microscopy. b-f. Frustules in external view. b. Frustule with a broken valve showing raphe in both valves. d, e. Note raphe terminal endings distant from the apices. e. Note the central trapezoidal area on the valve surface devoid of striae. $d$, f. Note elongated areolae at the valve mantle (arrowheads). g, h. Valves in internal view. g. Valve showing central raphe endings simple and straight and terminal raphe endings terminating in inconspicuous helictoglossae. h. Valve showing internally occluded areolae. Scale bars $=5 \mu \mathrm{m}(\mathrm{a}) ;=2 \mu \mathrm{m}(\mathrm{b}-\mathrm{h})$. / a. Microscopía óptica. Vista general de la valva. b-h. Microscopía electrónica de barrido. b-f. Frústulos en vista externa. b. Frústulo con una valva quebrada mostrando rafe en ambas valvas. d, e. Note extremos distales del rafe distantes de los ápices. e. Note el área trapezoidal central de la superficie valvar desprovista de estrías. d, f. Note areolas elongadas en el manto valvar (puntas de flecha). g, h. Valvas en vista interna. g. Valva mostrando extremos centrales del rafe simples y rectos y extremos distales terminando en inconspicuos helictoglossae. h. Valva mostrando areolas internamente ocluidas. Escalas $=5 \mu \mathrm{m}(\mathrm{a}) ;=2 \mu \mathrm{m}(\mathrm{b}-\mathrm{h})$. 

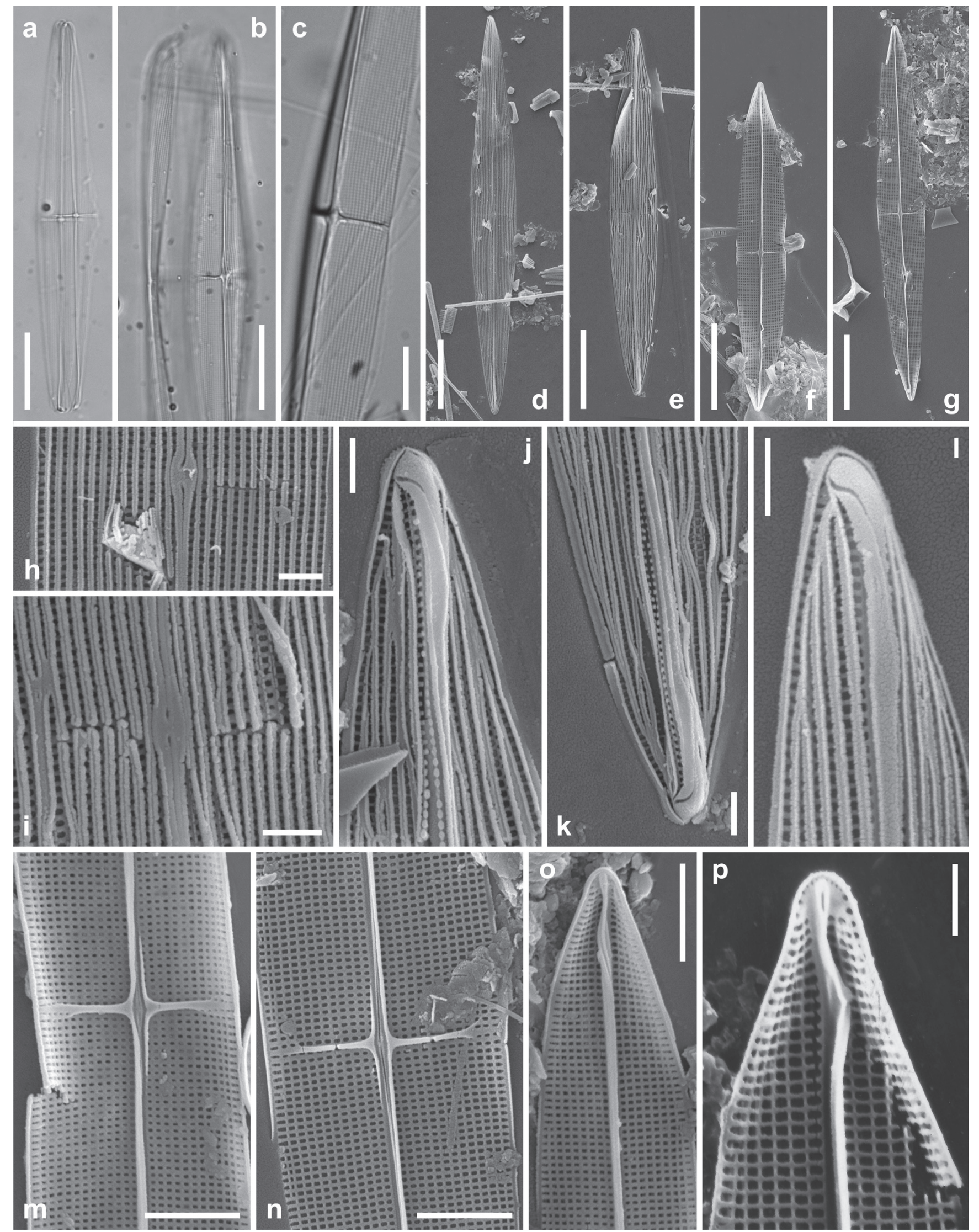
Figure 5. Haslea quarnerensoides. a-c. Light microscopy. Cleaned material. a, b. Frustules with fusiform valves showing central and straight raphe and pseudostauros. c. Note valve with transapical subtle striae crossed by delicate apical striae. d-p. Scanning electron microscopy. d, e, h-l. External views. d, e. General aspect of the valve. Note the longitudinal strips of silica separated by narrow slits. h, i. Central area of the valve. Note central raphe fissures. j-l. Apical area of valves. Note strongly deflected terminal raphe fissures. f, g, m-p. Internal view. $\mathrm{f}, \mathrm{g}$. General aspect of the valve. Note transapical striae, uniseriate and parallel throughout the valve. $\mathrm{m}, \mathrm{n}$. Central area of valve. Note axial ribs on the primary side of the valve, central ribs on the secondary side and pseudostauros continuous with both ribs. $\mathrm{o}$, p. Apical area of the valve. Note helictoglossa. Scale bars $=20 \mu \mathrm{m}$ (a, b, d-g); $10 \mu \mathrm{m}$ (c); $5 \mu \mathrm{m}$ (m-o); = $2 \mu \mathrm{m}$ (h-1, p). / a-c. Microscopía óptica. Material tratado. a, b. Frústulo con valvas fusiformes mostrando rafe central, recto y pseudostauros. c. Note valva con estrías transapicales sutiles cruzadas por delicadas estrías apicales. d-p. Microscopía electrónica de barrido. d, e, h-l. Vista externa. d, e. Aspecto general de la valva. Note las bandas longitudinales de sílice separadas por hendiduras estrechas. h, i. Área central de la valva. Note fisuras centrales del rafe. j-1. Área apical de las valvas. Note las fisuras terminales del rafe fuertemente desviadas. f, g, m-p. Vistas internas. f, g. Aspecto general de la valva. Note estrías transapicales uniseriadas y paralelas en toda la valva. m, n. Área central de la valva. Note la costilla axial del lado primario de la valva, la costilla central sobre el lado secundario y pseudostauros continuo con ambas costillas. o, p. Área apical de la valva. Note helictoglossae. Escalas $=20 \mu \mathrm{m}(\mathrm{a}, \mathrm{b}, \mathrm{d}-\mathrm{g}) ; 10 \mu \mathrm{m}(\mathrm{c}) ; 5 \mu \mathrm{m}(\mathrm{m}-\mathrm{o}) ;=2 \mu \mathrm{m}(\mathrm{h}-1, \mathrm{p})$.

Photographed material: LPC 4609, Las Grutas, 04/05/1999; LPC 4610, Punta Orengo, 04/07/1999; LPC 4625, El Sótano, 16/09/1999; LPC 13658, Piedras Coloradas 13/05/2006; LPC 13664, Las Grutas, 26/05/2006; LPC 13665, Piedras Coloradas 26/05/2006; LPC 13684, Las Grutas, 01/04/2007.

Distribution: This species was described from the Gulf of Naples, Mediterranean Sea as Navicula quarnerensoides (Hustedt 1961) and subsequently reported from the Caribean Sea as Haslea quarnerensoides by Navarro et al. (2000). The species was found only occasionally in all seasons of the year, scarce in phytoplankton samples from Las Grutas, Piedras Coloradas, Punta Orengo and El Sótano (Table 2). This is the first record of the species for South American coastal waters.
Sellaphoraceae

Fallacia A.J.Stickle \& D.G.Mann in Round, Crawford \& Mann 1990: 554, 667.

Fallacia margino-punctata K.Sabbe \& W.Vyverman in Sabbe, Vyverman \& Muylaert

References: Sabbe et al. 1999: 15, figs. 19-21, 28-33, 62-65. Fig. 6 a-f

Cells solitary, usually lying in valvar view. Elliptic valve, with broadly rounded apices, length $8-8.5 \mu \mathrm{m}$, and width 4.5-4.7 $\mu \mathrm{m}$ (Fig. 6 a, b) $(\mathrm{n}=8)$. Valve face flat, most part hyaline, poorly differentiated from shallow valve mantle (Fig. 6 a, b). In external view, striae formed by one transapically elongated, short areola, $28-30$ in $10 \mu \mathrm{m}$, closely located to valve mantle (Fig. 6 a, b), absent at the terminal areas around raphe branches (Fig. 6 d-f). Raphe straight to slightly curved (Fig. 6 a, b), and raphe branches
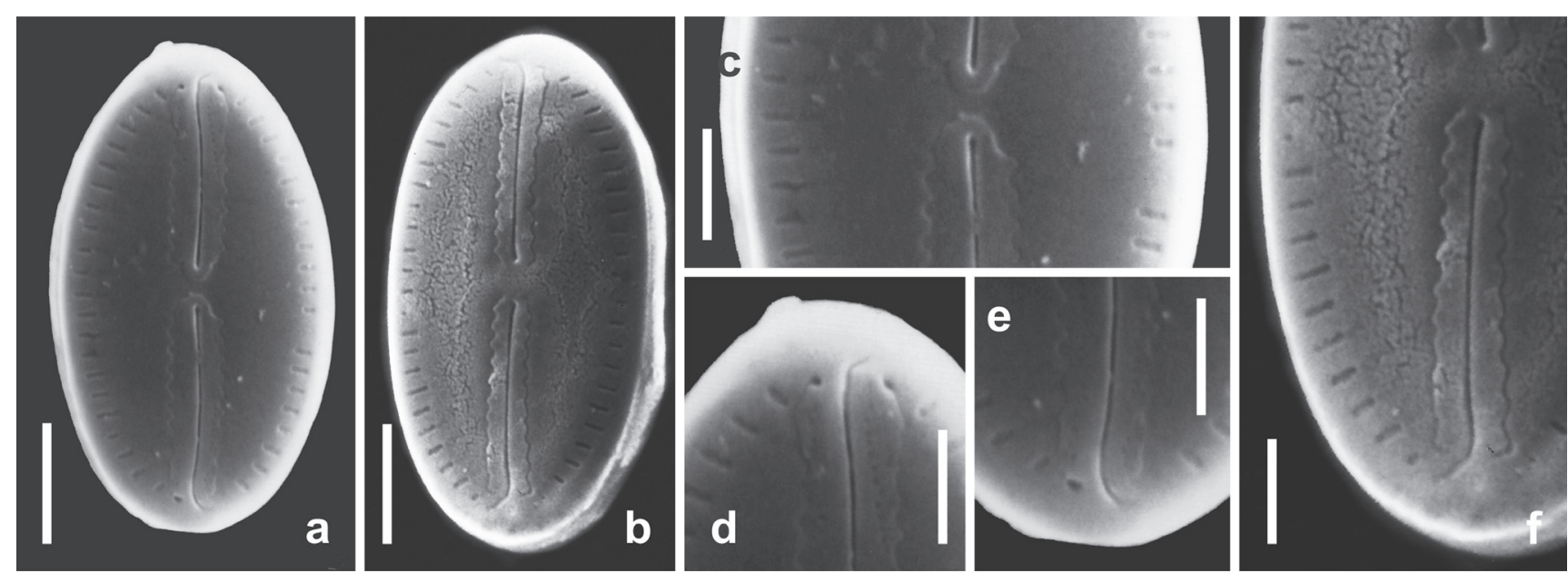

Figure 6. Fallacia margino-punctata. a-f. Scanning electron microscopy. External valve view. a, b. General aspect of the valve. c. Central area of the valve in fig. 6 a showing the conopeum. d, e. Poles of the same specimen in fig. 6 a. Note subtly porous conopeum and terminal raphe fissures deflected in the same direction and extended onto the valve mantle. $\mathrm{f}$. Detail of the valve illustrated in fig. $6 \mathrm{~b}$. Note transapically elongated areolae at the mantle. Scale bars $=2 \mu \mathrm{m}(\mathrm{a}, \mathrm{b}) ;=1 \mu \mathrm{m}(\mathrm{c}-\mathrm{f})$. / a-f. Microscopía electrónica de barrido. Vista valvar externa. a, b. Aspecto general de las valvas. c. Área central de la valva de la fig. 6 a mostrando el conopeum. d, e. Polos del mismo espécimen de la fig. 6 a. Note conopeum sutilmente poroso y fisuras terminales del rafe torcidas en la misma dirección y extendidas sobre el manto valvar. f. Detalle de la valva de la fig. 6 b. Note areolas transapicalmente elongadas en el manto. Escalas $=2 \mu \mathrm{m}(\mathrm{a}, \mathrm{b}) ; 1 \mu \mathrm{m}$ (c-f). 
surrounded by a narrow, parallel, subtly porous conopeum (Fig. 6 d, e), with crenulate margin (Fig. 6 a-f). External central raphe endings coaxial, barely expanded (Fig. 6 c), and terminal raphe fissures bent in same direction and extended onto valve mantle (Fig. 6 a, b, d-f).

Photographed material: LPC 4596, Las Grutas, 03/12/1998; LPC 4611, Los Alamos, 12/05/1999; LPC 13667, Piedras Coloradas, 14/06/2006.

Distribution: Fallacia margino-punctata was described from sandy intertidal sediments in the mouth of the Westerschelde estuary (The Netherlands) and was also found, based on analysis of Hustedt's material, from the Wadden Sea (Germany), Beaufort (USA) and of Salah's material from Blakeney Point, Norfolk (Great Britain) by Sabbe et al. (1999). The species was found only occasionally during fall, winter and spring, scarce in phytoplankton samples from Piedras Coloradas, Las Grutas and Los Alamos (Table 2). This is the first record of the species for South American coastal waters.

Fallacia vittata (Cleve) D.G. Mann in Round, Crawford \& Mann

Fig. 7 a-g

Basionym: Diploneis bioculata var. vittata Cleve 1894: 80, pl. 1, fig. 15.

Synonym: Navicula vittata (Cleve) Hustedt 1955: 22, pl. 8, figs. 3-5, 12.

References: Round et al. 1990: 670, Garcia 2003: 315, figs. 54-60.

Cells solitary, usually lying in valvar view. Elliptic valve with bluntly rounded apices, length 14-35 $\mu \mathrm{m}$, and width 8-17 $\mu \mathrm{m}$ (Fig. 7 a-d) $(\mathrm{n}=7)$. Raphe slightly arched towards apices, with external central endings distant (Fig. 7 a-f). In LM, striae straight and almost parallel at centre becoming radiate and curved towards apices, $16-18$ in $10 \mu \mathrm{m}$; striae distally interrupted by a hyaline area into two parts, a long proximal part and a short marginal part (Fig. 7 a). Hyaline area symmetric, located next to margin of valve surface (Fig. 7 a, d, f). In SEM, valve surface almost flat curving down at edges and stepping to mantle (Fig. 7 b-d). Striae uniseriate. Areolae irregularly distributed along proximal part of striae, and gathered from one to three at distal part of striae (Fig. 7 d, f). Areolae externally covered by a porous conopeum (Fig. 7 e arrows) supported by struts placed between striae (Fig. $7 \mathrm{f}$ arrows). Areolae open to outside at poles (Fig. $7 \mathrm{~g}$ arrowheads). Pores on conopeum multiseriately arranged above each striae (Fig. 7 e arrows). Lateral raphe-sternum internally depressed (Fig. $7 \mathrm{a}, \mathrm{d}, \mathrm{f}$ ), externally concealed by conopeum that reaches mantle (Fig. 7 b, c). A ring of submarginal pegs located between conopeum and oblique valve mantle (Fig. 7 e, f arrowheads). Central fissures distantly spaced, dug out on central area, ending in expanded drop-like pores, and weakly unilaterally bent towards one valve margin (Fig. 7 b-f). Terminal raphe fissures deflected in same direction as central fissures, to one side of apex ending close to valve margin (Fig. 7 b, c, g). Valve mantle at apices with few pores on both sides of raphe fissures (Fig. 7 d, g).

Photographed material: LPC 4563, El Fuerte, 04/05/1998; LPC 4596, Las Grutas, 03/12/1998.

Distribution: Fallacia vittata was described by Cleve (1894) from Ceylon. Hustedt (1955) mentioned it as a species widely distributed on warmer coasts and found it in marine littoral waters of Beaufort, North Carolina, and Witkowski et al. (2000) considered the taxon as widespread in marine littoral habitats. Sar (1996) recorded it for first time from Argentinean coastal waters in the same area of this study, as Navicula vittata. Subsequently Garcia (2003) recorded it from Brazilian coastal waters. F. vittata was found only occasionally in phytoplankton samples from Las Grutas, Piedras Coloradas, El Sótano and El Fuerte, in fall, winter and spring (Table 2).

\section{DISCUSSION}

Specimens of Berkeleya rutilans analyzed in the present study are similar to those found by Fricke et al. (2017). The analyzed specimens differ from those shown by Cox (1975) and Lobban (1985) by having a higher stria density (30-34 in $10 \mu \mathrm{m}$ vs. 27 in $10 \mu \mathrm{m}$, in the valve centre) and better agree with those described by Mizuno (1977) (24-36 in $10 \mu \mathrm{m}$ ). Recently, Hamsher \& Saunders (2014) utilized DNA barcode data to assign marine tube-forming diatoms from Canada to genetic species groups; they uncovered an unexpected diversity within taxa identified under $B$. rutilans. These authors highlighted the importance of combining morphological and molecular tools to reveal the full extent of species diversity in the genus. Stria density of morphological unnamed species delimited by Hamsher \& Saunders (2014), was lower than that specimens described from the Gulf of San Matías material.

Analyzed material of Amicula specululum is similar to that from Puck Bay, Poland (Witkowski 1994), Indian Ocean coast in Kenya (Witkowski et al. 2000) and Caspian Sea (Karayeva \& Bukhtiyarova 2010); nevertheless it differs by having a higher stria density. Distribution of the genus and the species is extended to South America coastal waters.

Cocconeiopsis pullus was considered a species occurring in subtropical areas of America by Garcia \& Bärwaldt Dutra (2013). Nevertheless, it was found in the Black Sea by Nevrova (2016) and in temperate area of Argentinean coastal waters in this study. Distribution of the genus and the species is extended to Argentina. 

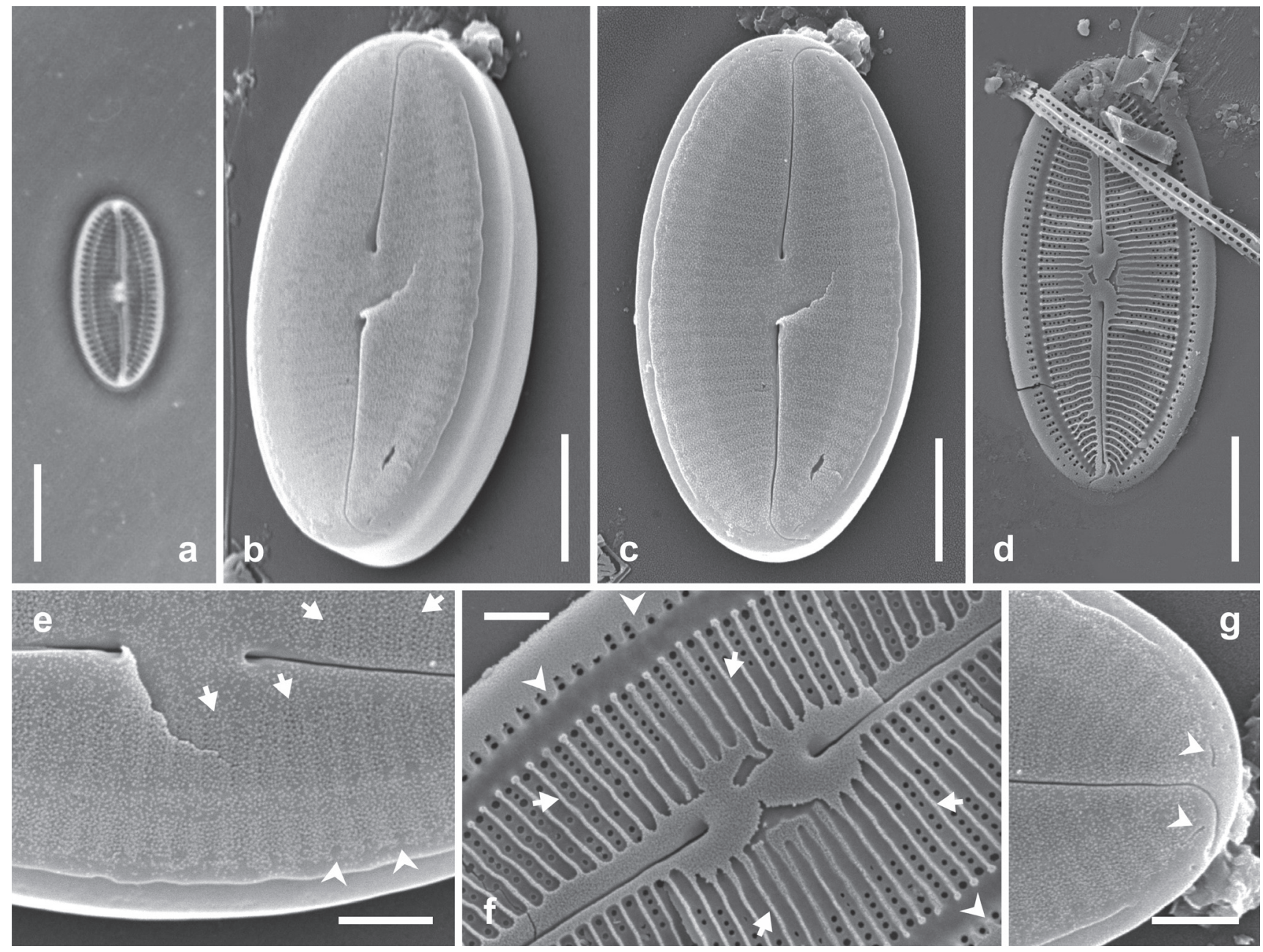

FIGURE 7. Fallacia vittata. a. Light microscopy. Valve showing striae distally interrupted by a hyaline area. b-g. Scanning electron microscopy. b. Tilted frustule showing the stepped mantle. c. Valve with porous conopeum covering the striae and raphe slightly arched towards the apices. d. Valve with the conopeum completely eroded showing the lateral raphe-sternum depressed towards the inner side. e. Pores on conopeum bi or multiseriately arranged above each striae (arrows). f. Valve showing the struts placed between the striae (arrows) and the ring of submarginal pegs (arrowheads). g. Apex of the valve showing terminal raphe fissure and a few isolated pores on both sides of it. Arrowheads show the external openings of the conopeum at the poles. Scale bars $=10 \mu \mathrm{m}(\mathrm{a}, \mathrm{d}) ;=5 \mu \mathrm{m}(\mathrm{b}, \mathrm{c}) ;=2 \mu \mathrm{m}(\mathrm{e}-\mathrm{g})$. / a. Microscopía óptica. Valva mostrando estrías distalmente interrumpidas por un área hialina. b-g. Microscopía electrónica de barrido. b. Frústulo inclinado mostrando manto escalonado. c. Valva con conopeum poroso cubriendo las estrías y rafe ligeramente arqueado hacia los ápices. d. Valva con conopeum completamente erosionado mostrando el rafe-esternón deprimido hacia el lado interno. e. Poros del conopeum multiseriadamente arreglados sobre cada estría (flechas). f. Valva mostrando puntales colocados entre las estrías (flechas) y el anillo de clavijas submarginales (puntas de flecha). g. Ápice de la valva mostrando fisuras terminales del rafe y unos pocos poros aislados sobre cada lado de él. Puntas de flecha muestran las aberturas externas del conopeum en los polos. Escalas $=10 \mu \mathrm{m}(\mathrm{a}, \mathrm{d}) ;=5 \mu \mathrm{m}(\mathrm{b}, \mathrm{c})$; $=2 \mu \mathrm{m}(\mathrm{e}-\mathrm{g})$. 
Haslea quarnerensoides was previously analyzed with SEM by Navarro et al. (2000). However, several diagnostic features remained undescribed until this study. Distribution of the species is extended to the American Continent.

Analyzed material of Fallacia margino-punctata perfectly matches material from Westerchelde estuary, The Netherlands (Sabbe et al. 1999). Distribution of the species is extended to South American coastal waters.

Fallacia vittata and Berkeleya rutilans, considered as widespread in marine littoral habitats by Hustedt (1955) and Witkowski et al. (2000), are the only taxa from the Naviculales in this study that have been previously reported for temperate coastal waters around Patagonia (Argentina).

It would be valuable in the future to sample the benthic diatom assemblages to get a complete analysis of the Naviculales, for this region of South America.

\section{ACKNOWLEDGEMENTS}

The research was supported by grants from the Universidad Nacional de La Plata 11/N516, and from the Consejo Nacional de Investigaciones Científicas y Técnicas, PIP 5312. The authors thank Oscar Romero and another anonymous reviewer for giving us help to improve our work.

\section{REFERENCES}

Cefarelli, A.O., Mascioni, M., Simonato, J., Almandoz, G.O., VERnET, M. 2018. Haslea crucigeroides var. australis, var. nov. (Bacillariophyta), a new marine diatom from southern South America and Antarctica. Phytotaxa 357(3): 179-188.

Cleve, P.T. 1894. Synopsis of the Naviculoid Diatoms. Kongliga Svenska Vetenakaps-Akademiens Handligar 26(2): 1-194.

Cox, E.J. 1975. Further studies on the genus Berkeleya Grev. British Phycological Journal 10(2): 205-217.

Ferrario, M.E., SAR, E.A. 1984. Diatomeas pennadas de la Ría de Puerto Deseado (Prov. de Santa Cruz) II. S.O.Raphidiineae. Revista del Museo de La Plata 13 (n. s.) Botánica 8: 217 211.

Ferrario, M.E., SAR, E.A. 1990. Ultraestructura de Pleurosigma chilensis var. patagonica nov. var. (Bacillariophyceae). Darwiniana 30(1-4): 201-204.

Ferrario, M.E., SAR, E.A., SAla, S.E. 1995. Metodología básica para el estudio del fitoplancton con especial referencia a las diatomeas. En: Alveal, K., Ferrario, M.E., Oliveira, E.C., Sar, E.A. (eds.), Manual de métodos ficológicos, pp. 1-23. Universidad de Concepción, Concepción.

Fricke, A., Kihara, T.C., Kopprio, G.A., Hoppenrath, M. 2017. Anthropogenically driven habitat formation by a tube dwelling diatom on the Northern Patagonian Atlantic coast. Ecological Indicators 77: 8-13.

Garcia, M. 2003. Observations on the diatom genus Fallacia (Bacillariophyta) from southern Brazilian sandy beaches. Nova Hedwigia 77(3-4): 309-330.

Garcia, M., BÄrwaldt Dutra, D. 2013. Morfologia e distribuição de Cocconeiopsis Witkowski, Lange-Bertalot \& Metzeltin no litoral de Santa Catarina, Brasil. Iheringia, Série Botânica 68(2): 215-224.

HAMShER, S.E., SAundERS, G.W. 2014. A floristic survey of marine tube-forming diatoms reveals unexpected diversity and extensive co-habitation among genetic lines of the Berkeleya rutilans complex (Bacillariophyceae). European Journal of Phycology 49(1): 47-59.

Hasle, G.R., Fryxell, G.A. 1970. Diatoms: cleaning and mounting for light and electron microscopy. Transactions of the American Microscopical Society 89(4): 469-474.

Hustedt, F. 1955. Marine littoral diatoms of Beaufort, North Carolina. Duke University Marine Station, Bulletin 6: 1-67.

Hustedt, F. 1961. Die Kieselalgen Deutschlands, Österreichs und der Schweiz. In: Rabenhorst, L. (ed.), Kryptogamenflora von Deutschland, Österreichs und der Schweiz 7(1), pp. 1-160. Akademische Verlagsgesellschaft, Leipzig.

Karayeva, N.I., Bukhtiyarova, L.N. 2010. An addition to the Bacillariophyta flora of the Caspian Sea. I. Algologia 20(4): 471-481. [In Russian].

LoBban, C.S. 1984. Marine tube-dwelling diatoms of eastern Canada: descriptions, checklist, and illustrated key. Canadian Journal of Botany 62(4): 778-794.

LobBan, C.S. 1985. Marine tube-dwelling diatoms of the Pacific coast of North America. I. Berkeleya, Haslea, Nitzschia, and Navicula sect. Microstigmaticae. Canadian Journal of Botany 63(10): 1779-1784.

Maidana, N.I., Romero, O.E. 1995. Diatoms from the hypersaline "La Amarga" lake (La Pampa, Argentina). Cryptogamie Algologie 16(3): 173-188.

Massé, G., Rincé, Y., Cox, E.J., Allard, G., Belt, S.T., Rowland, S.J. 2001. Haslea salstonica sp. nov. and Haslea pseudostrearia sp. nov. (Bacillariophyta), two new epibenthic diatoms from the Kingsbridge estuary, United Kingdom. Comptes Rendus de l'Academie des Sciences de Paris, Sciences de la vie/Life Sciences 324: 617-626.

Mizuno, M. 1977. On the tube-dwelling diatom Berkeleya rutilans (Trentepohl) Grun. Bulletin of the Japanese Society of Phycology 25: 143-149. [In Japanese].

Navarro, J.N., Micheli, C.J., Navarro, A.O. 2000. Benthic diatoms of Mona Island (Isla de Mona), Puerto Rico. Acta Científica 14(3): 103-143.

Nevrova, E.L. 2016. The composition and structure of the benthic diatom taxocene (Bacillariophyta) near Cape Fiolent (the Crimea, the Black Sea). Russian Journal of Marine Biology 42(5): 392-401.

Pascual, M.S., Zampatti, E.A., Iribarne, O.O. 2001. Population structure and demography of the puelche oyster (Ostrea puelchana, D'Orbigny, 1841) grounds in Northern Patagonia, Argentina. Journal of Shellfish Research 20(3): 1003-1010.

Prygiel, J., Coste, M. 2000. Guide Méthodologique pour la mise en ouvre de 1'Indice Biologique Diatomées. Agences de l'Eau, Ministère de l'Aménagement du Territoire et de l'Environnement, Direction de l'Eau \& CEMAGREF, France, $134 \mathrm{pp}$.

Ross, R., Cox, E.J., Karayeva, N.I., Mann, D.G., Paddock, T.B.B., Simonsen, R., Sims, P.A. 1979. An amended terminology for the siliceous components of the diatom cell. In: Simonsen, R. (ed.), Proceedings of the Fourth Symposium on Recent and Fossil Marine Diatoms. Nova Hedwigia, Beiheft 64: 513-533.

Roтн, A.G. 1806. Catalecta botanica. (Quibus plantae novae et minus cognitae describuntur atque illustrantur). Fasciculus 
tertius cum tabulis aenaeis XII. Bibliopolio Io. Fr. Gleditschiano, Lipsiae [Leipzig], 360 pp.

Round, F.E., Crawford, R., Mann, D.G. 1990. The Diatoms. Morphology and Biology of the Genera. Cambridge University Press, London, 745 pp.

Sabbe, K., Vyverman, W., Muylaert, K. 1999. New and littleknown Fallacia species (Bacillariophyta) from brackish and marine intertidal sandy sediments in Northwest Europe and North America. Phycologia 38(1): 8-22.

SAR, E.A. 1996. Flora diatomológica de Bahía San Antonio (Prov. de Río Negro, Argentina) Pennales I. Revista del Museo de La Plata 14 (n.s.) Botánica 107: 399-430.

Sar, E.A., Hinz, F., Sterrenburg, F.A.S., Lavigne, A.S., Lofeudo, S., Sunesen, I. 2012. Species of Pleurosigma (Pleurosigmataceae) with lanceolate or slightly sigmoid valve outline. Analysis of type materials. Diatom Research 27(3-4): 237-253.

Sar, E.A., Sterrenburg, F.A.S., Lavigne, A.S., Sunesen, I. 2013. Diatomeas de ambientes marinos costeros de Argentina. Especies del género Pleurosigma (Pleurosigmataceae). Boletín de la Sociedad Argentina de Botánica 48(1): 17-51.

Sar, E.A., Sterrenburg, F.A.S., Sunesen, I. 2014. Pleurosigma hinzianum $\mathrm{sp}$. nov. and $P$. frenguellianum $\mathrm{sp}$. nov.
(Pleurosigmataceae, Bacillariophyta) from Argentinean coastal waters, in comparison with $P$. amara Stidolph and P. elongatum W. Smith. European Journal of Phycology 49(2): 151-164.

Simonsen, R. 1974. The diatom plankton of the Indian Ocean Expedition of R/V 'Meteor' 1964-1965. 'Meteor' Forschungsergebnisse Reihe D 19: 1-107.

Simonsen, R. 1987. Atlas and Catalogue of the Diatom Types of Friedrich Hustedt. J. Cramer, Berlin-Stuttgart, Vols 1-3. 1, pp 524; 2, pls 1-395; 3, pls 396-772.

Sunesen, I., Sterrenburg, F.A.S., Sar, E.A. 2013. Pleurosigma guarreranum, sp.nov. (Pleurosigmataceae, Bacillariophyta), from the Gulf of San Matías, Argentina and comparison with the allied species Pleurosigma exemptum and $P$. obesum. European Journal of Phycology 48(4): 451-460.

Witkowski, A. 1994. Recent and fossil diatom flora of the Gulf of Gdańsk, southern Baltic Sea. Origin, composition and changes of diatom assemblages during the Holocene. Bibliotheca Diatomologica 28: 1-313.

Witkowski, A., Lange-Bertalot, H., Metzeltin, D. 2000. Diatom flora of marine coast I. Iconographia Diatomologica 7: $1-925$.

Recibido: 14.03 .2018

Aceptado: 17.12 .2018 